\title{
Morphometric Study of the Pterion in Dry Human Skulls in Northeastern Brazil
}

\author{
Jalles Dantas de Lucena, ${ }^{1}$ João Victor Souza Sanders, ${ }^{2}$ Hudson Martins de Brito, ${ }^{2}$ Michelly Carneiro Collyer, ${ }^{2}$ Gilberto Santos \\ Cerqueira, ${ }^{3}$ Desiré Dominique Diniz de Magalhães, ${ }^{4}$ André de Sá Braga Oliveira ${ }^{5}$
}

'Postgraduate Program in Morphofunctional Sciences, Universidade Federal do Ceará (UFC) Fortaleza, CE, Brazil.

${ }^{2}$ School of Medicine, Universidade Federal do Ceará (UFC), Fortaleza,CE, Brazil

${ }^{3}$ Departament of Morphology, Universidade Federal do Ceará (UFC), Fortaleza, CE, Brazil.

${ }^{4}$ School of Speech Therapy, Universidade Federal da Paraíba (UFPB), João Pessoa, PB, Brazil

Departament of Morphology, Universidade Federal da Paraíba (UFPB),João Pessoa, PB, Brazil

Disclose and conflicts of interest: none to be declared by all authors

\begin{abstract}
Introduction: The pterion is an anatomical craniometric point that marks the conflu-ence of sutures between the frontal, parietal, sphenoid and temporal bones. It has a variety of types that have been found and described. Proper knowledge of pterion morphology could improve microneurosurgeries that use pterional approaches. Therefore, the current study aims to analyze the morphology and morphometry of the pterion in human skulls from the Northeastern region of Brazil. Materials and Methods A total of 54 dry adult human skulls were analyzed in the present study. They were classified according to gender and to the pattern of the pterion. The epipteric bone was also classified. Linear measurements were taken bilaterally using a digital caliper. Values of $p \leq 0.05$ were considered significant.

Results: The most common type of pterion found was the sphenoparietal (both in males and females). No differences between gender or side were found for the morphometric parameters analyzed ( $p>0.05$ ). The present study showed that $12.96 \%$ of the skulls had an epipteric bone. The unilateral presentation was more common than the bilateral one. Conclusion: The present is the first study that shows sexual dimorphism regarding the types and morphometric parameters of the pterion in a population from the Northeastern region of Brazil, and it showed a similar pattern of pterion types when compared with the data in the current literature, but different values for all morphometric parameters analyzed. These results might help neurosurgeons use this craniometric point to access a variety of brain lesions in individuals from Northeastern Brazil, decreasing the rates of iatrogenic lesion and increasing the rates of successful outcomes.
\end{abstract}

Keywords: Anatomy; Pterion; Skull; Brazil.

\section{Introduction}

The pterion is an anatomical craniometric point located at the lateral region of the skull, superior to the zygomatic arch and posterior to the frontozygomatic suture. ${ }^{1}$ It marks the confluence of sutures between four cranial bones: the frontal, parietal, sphenoid and squamous temporal bones. ${ }^{2,3}$ In the skull of neonates, the pterion corresponds to the site of the anterolateral fontanelle, which closes three months after birth. ${ }^{3}$

The pterion presents anatomical variations. Murphy ${ }^{4}$ classified it into 4 types: sphenoparietal (SP), frontotemporal (FT), stellate (ST) and epipteric (EP, due to the formation of a bone or bones). The SP type is due to the direct contact of the sphenoid and parietal bones. The FT type is named so because of the contact of the frontal and temporal bones, and the ST type is characterized by the articulation of four bones (the frontal, parietal, temporal and sphenoid bones). ${ }^{3}$ The EP type forms a sutural bone called the epipteric bone. Broek $^{5}$ classified this bone as: epiptericum typicum, anterius, posterius, superius, inferius, bilaterum, and ossa epipterica.

The pterion is also an important anatomical reference because the insula and Broca motor speech area (in the left cerebral hemisphere) are found there, and it is where the stem of the lateral sulcus of the cerebral hemisphere divides (the Sylvian point) into its three limbs: the anterior, the ascending and the posterior limbs. Furthermore, beneath this area runs the anterior branch of the middle meningeal artery, which marks the inner surface of the skull, and its main clinical importance is because traumas in these areas can rupture this artery and cause an extradural hematoma. ${ }^{3,6}$

The pterion is a crucial intraoperative landmark for surgical approaches for craniotomy and for the treatment of various diseases that require access to the structures of the anterior and middle cranial fossae, such as removing tumors involving inferior aspects of the frontal lobe, olfactory meningiomas, and traumatic optic neuropathy. ${ }^{3,7,8}$ This explains the 
need to know the variations of the pterion, because, since it can fracture easily, this may cause surgical complications. ${ }^{6,7}$

Due to the variety that has been found and described, ${ }^{2}$ the pterion has been generating interest in many areas, such as anthropology, anatomy, pathology and forensic science. ${ }^{8}$ Proper knowledge of the measurements and classifications of the pterion could improve the success rate of minimally-invasive microneurosurgeries that are performed using pterional approaches. The present study was motivated by the scarcity of studies in the Brazilian literature about the characteristics of the pterion. Therefore, the objective of the current study was to analyze the morphology and morphometry of the pterion in human skulls from the Northeastern region of Brazil.

\section{Material and Methods}

A total of 54 dried human adult skulls of unknown ethnicity and without any gross pathologies or abnormalities were analyzed. The skulls were obtained from the Human Anatomy Laboratories of Universidade Federal do Ceará (UFC) and Universidade Federal da Paraíba (UFPB), in the Northeastern region of Brazil. Only skulls with the pterion and other anatomical structures left intact on at least one side were used in the present study.

First, the skulls were classified according to gender, based on the morphological features described by Vanrell. ${ }^{9}$ The sutural patterns of the pterion (SP, FT, ST and EP) were determined on both sides ${ }^{4}$ (Fig. 1). The epipteric bone was described according to the Broek classification (Fig. 2).

Then, linear measurements were taken bilaterally from the center of the pterion to the frontozygomatic suture (P-FZS), the midpoint of the zygomatic arch (P-MZA), and the center of the external acoustic meatus (P-EAM) (Fig. 3).

The measurements were taken using a digital caliper with an accuracy of $0.01 \mathrm{~mm}$. The Student t-test was applied to evaluate the differences between gender and type of pterion on each side using the GraphPad Prism (GraphPad Software, San Diego, CA, US) software, version 6.00 for Windows. Values of $p$ $<0.05$ were considered significant.
A total of 54 dry adult human skulls (29 male and 25 female skulls) were used in the study. Since 10 skulls were analyzed only on only one side due to damaged structures, in total, the analysis involved 98 sides.

As for the pterion classification, 4 types were observed: $85.71 \%$ were of the SP type (males: $50 \%$; females: $35.71 \%$ ); $3.06 \%$ were of the FT type (only found in females); $3.06 \%$ were of the ST type (males: $1.02 \%$; females: $2.04 \%)$; $8.16 \%$ were of the EP type $(4.08 \%$ for each gender). The SP type was the most observed on both sides, with $85.71 \%$ (35 cases) (Table 1).

The mean value of the P-FZSwas of $35.06 \pm 6.33 \mathrm{~mm}$ (range: $22.36-48.10 \mathrm{~mm}$ ) on the right side, and of 34.89 $\pm 4.63 \mathrm{~mm}$ (range: $25.20-42.60 \mathrm{~mm}$ ) on left side in males. In females it was of $34.58 \pm 6.20 \mathrm{~mm}$ (range: $16.60-45.70 \mathrm{~mm}$ ) on the right side, and of $32.89 \pm 6.93$ $\mathrm{mm}$ (range: $13.70-47.60 \mathrm{~mm}$ ) on the left side (Table 2).

In males, the mean value of the P-MZA was of $42.43 \pm$ $3.98 \mathrm{~mm}$ (range: $36.40-48.70 \mathrm{~mm}$ ) on the right side, and of $42.22 \pm 5.01 \mathrm{~mm}$ (range: $31.20-50.10 \mathrm{~mm}$ ) on the left side, and, in females, it was of $41.42 \pm 4.69 \mathrm{~mm}$ (range: $34.20-53.20 \mathrm{~mm}$ ) on the right side, and of $41.42 \pm 5.17$ $\mathrm{mm}$ (range: $32.90-54.40 \mathrm{~mm}$ ) on the left side (Table 2).

As for the mean value of the P-EAM, in males, it was of $58.09 \pm 3.17 \mathrm{~mm}$ (range: $52.0-67.80 \mathrm{~mm}$ ) on the right side, and of $58.70 \pm 3.59 \mathrm{~mm}$ (range: $50.90-68.0 \mathrm{~mm}$ ) on the left side, and, in females, it was of $56.06 \pm 4.17 \mathrm{~mm}$ (range: $47.20-65.40 \mathrm{~mm}$ ) on the right, and of $57.04 \pm$ $3.78 \mathrm{~mm}$ (range: $50.10-64.80 \mathrm{~mm}$ ) on the left side (Table 2). No statistical differences between the right and left sides and regarding gender were observed in any of the parameters analyzed $(p>0.05)$.

In the present study, 7 (12.96\%) skulls had an epipteric bone. The unilateral presentation (11.11\%) was more common than the bilateral one (1.85\%).

\section{Discussion}

Human skulls may have morphological and morphometrical variations depending on gender, ethnicity, and environmental and genetic factors. ${ }^{1,10,11}$ The pterion is the most commonly used surface landmark by neurosurgeons; thus,

modifications in this region may cause surgical problems with a wrong access. ${ }^{12}$

\section{Results}

SPENOPARIETAL TYPE

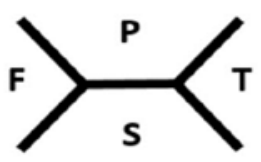

FRONTOTEMPORAL TYPE

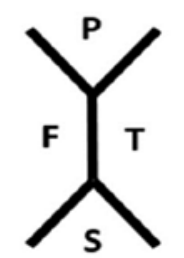

STELLATE TYPE

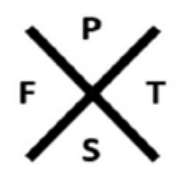

EPIPTERIC BONE

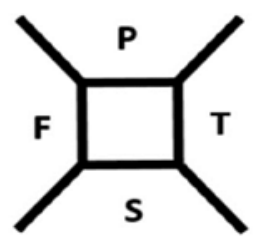

Figure 1. Classification of pterion types by Murphy. ${ }^{4}$ Abbreviations: $\mathrm{P}$ - parietal bone; $\mathrm{F}$ - frontal bone; $\mathrm{S}$ - sphenoid bone; $\mathrm{T}$ - temporal bone. 


\section{EPIPTERIUM} TYPICUM

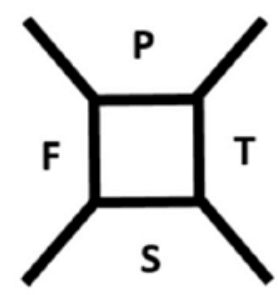

\section{EPIPTERIUM ANTERIUS}

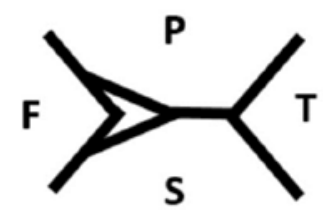

\section{EPIPTERIUM POSTERIUS}

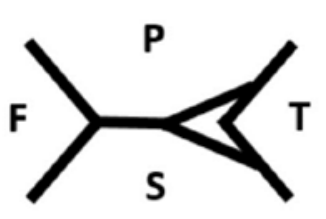

EPIPTERIUM SUPERIUS

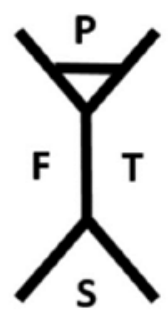

\section{EPIPTERIUM INFERIUS}

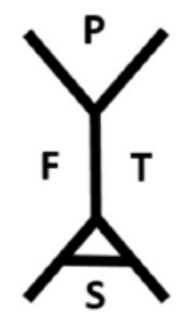

\section{EPIPTERIUM} BILATERUM
OSSA EPIPTERICA

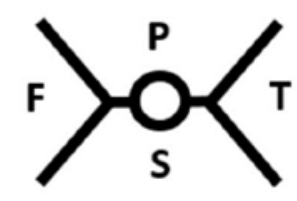

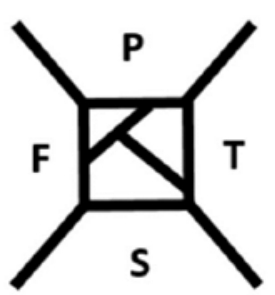

Figure 2. Classification of epipteric bones by BroekAbbreviations: $\mathrm{P}$ - parietal bone; F - frontal bone; $\mathrm{S}$ - sphenoid bone; $\mathrm{T}$ - temporal bone.

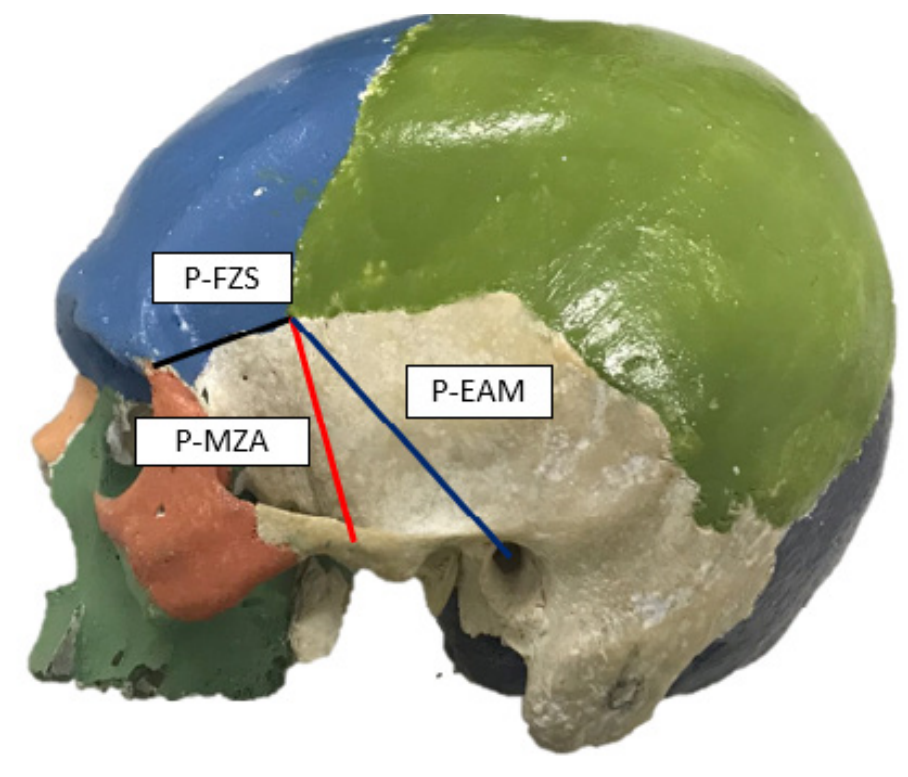

Figure 3. Left-side view of the skull showing the distance from the center of the pterion to the following bony landmarks: the Frontozygomatic Suture (P-FZS), the Midpoint of Zygomatic Arch (P-MZA), and the center of the External Acoustic Meatus (P-EAM).

Table 1. Distribution of Pterion types according to gender $(n-98)$

\begin{tabular}{l|c|c|c}
\hline Types of Pterion & $\begin{array}{c}\text { General } \\
\text { (\%) }\end{array}$ & $\begin{array}{c}\text { Mas kulls } \\
\text { (\%) }\end{array}$ & $\begin{array}{c}\text { Female skulls } \\
\text { (\%) }\end{array}$ \\
\hline Sphenoparietal & 85.71 & 50 & 35.71 \\
\hline Frontotemporal & 3.06 & - & 3.06 \\
\hline Stellate & 3.06 & 1.02 & 2.04 \\
\hline Epipteric & 8.16 & 4.08 & 4.08 \\
\hline
\end{tabular}

The SP type was the most common in the present study; the same finding was observed in studies performed in India, ${ }^{2,3,10,12-25}$ Turkey, ${ }^{6,7,26}$ Nigeria, ${ }^{1,8,22,27}$ Kenya, ${ }^{28}$ Mexico, ${ }^{29}$ Thailand $^{30}$ and Brazil ${ }^{31}$ (Table 3). This can be explained by the evolutionary theory of primates: the anterosuperior segment of the squamous part of the temporal bone of primates stood out from their parent and was incorporated into the posterolateral angle of the greater wing of the human sphenoid bone, thus changing the FT pterion pattern of primates to the SP type of humans. ${ }^{8,25}$

The incidence of the FT type has a wide variation among countries and also among different regions of the same country, as was shown in Indian studies, in which the incidence ranges from $1 \%{ }^{2}$ to $17.35 \%{ }^{32}$ In the present study, this percentage was similar to one of the smallest values found in India (3.1\%), and the FT type was only observed in the female skulls (Table 3 ).

The ST type was present in $3.06 \%$ of our sample, which is very similar to the prevalence found in the study by Zalawadia et al. ${ }^{25} 1.2 \%$. Moreover, the prevalence of the ST type is particularly high in Turkey ${ }^{6}$ compared with other populations.

The incidence of the EP type also varies greatly, from $1.43 \%{ }^{31}$ to $23.3 \% .^{18}$ This type can also be calledWormian bone, which is an accessory skull bone surrounded by a suture. It can be found in individuals with osteogenesis imperfecta, which is characterized by the presence of several Wormian bones. Many studies ${ }^{18,33}$ associate the pterion with Wormian bones, but the type of pterion is observed during the second and third months of intrauterine life, and Wormian bones appear quite late after the full development of the neighboring bones. 
Table 2. Mean $(\mathrm{mm}) \pm \mathrm{SD}$ values of Pterion measurements according to gender $(n=98)$

\begin{tabular}{|c|c|c|c|c|c|c|c|c|}
\hline & MALE & & & & FEMALE & & & \\
\hline & Right side & & Left side & & Right side & & Left side & \\
\hline Parameters & Min.- Max. & Mean (SD) & Min.- Max. & Mean (SD) & Min.- Max. & Mean (SD) & Min.- Max. & Mean (SD) \\
\hline P-FZS & $22.36-48.10$ & $35.06(6.33)$ & $25.20-42.60$ & $34.89(4.63)$ & $16.66-45.70$ & $34.58(6.20)$ & $13.70-47.60$ & 32.89 (6.93) \\
\hline P-MZA & $36.40-48.70$ & $42.43(3.98)$ & $31.20-50.10$ & $42.22(5.01)$ & $34.20-52.20$ & $41.42(4.69)$ & $32.90-54.40$ & 41.42 (5.17) \\
\hline P-EAM & $52.0-67.80$ & 58.09 (3.17) & $50.90-68.0$ & 58.70 (3.59) & $47.20-65.40$ & $56.06(4.17)$ & $50.10-64.80$ & $57.04(3.78)$ \\
\hline
\end{tabular}

Abbreviations: Max., maximum*; Min, minimum*; n, number; P-EAM, distance from the pterion to the center of the external acoustic meatus; P-FZS, distance from the pterion to the frontozygomatic suture; P-MZA, distance from the pterion to the midpoint of the zygomatic arch; SD, standard deviation.

Table 3. Comparison of the distribution of pterion types in different populations $(n=98)$

\begin{tabular}{|c|c|c|c|c|c|c|}
\hline \multirow{2}{*}{ Population } & \multirow{2}{*}{ Gender } & \multirow{2}{*}{ n (sides) } & \multicolumn{4}{|c|}{ Type of pterion (\%) } \\
\hline & & & SP & FT & EP & ST \\
\hline \multirow[t]{2}{*}{ Seema et al, ${ }^{2}$ Mysore, India } & Male & 54 & 92.6 & 1.8 & 1.8 & 3.7 \\
\hline & Female & 46 & 95.7 & 0 & 4.3 & 0 \\
\hline Adejuwon et al, Southwestern region of Nigeria & Not specified & 74 & 86.1 & 8.3 & 0 & 5.7 \\
\hline \multirow[t]{2}{*}{ Mwachaka et al, ${ }^{28}$ Kenya } & Male & 94 & 69.4 & 14.5 & 4.8 & 11.3 \\
\hline & Female & 64 & 60.5 & 15.8 & 10.5 & 13.2 \\
\hline Saheb et al, ${ }^{32}$ India & Not specified & 250 & 69.25 & 17.35 & 9.7 & 3.7 \\
\hline Gindha et $a l_{,}^{13}$ North of India & Not specified & 130 & 72.31 & 4.61 & 23.08 & 0 \\
\hline Sindel et al, ${ }^{6}$ Turkey & Not specified & 300 & 63 & 2 & 16 & 19 \\
\hline Rao et al, ${ }^{3}$ Telangana, India & Not specified & 140 & 80 & 3.57 & 9.28 & 7.14 \\
\hline Aksu et al,7 West Anatolian region of Turkey & Not specified & 256 & 85.2 & 1.1 & 8.2 & 5.5 \\
\hline Avalos et al, ${ }^{29}$ Mexico & Not specified & 170 & 90 & 2.4 & 3.5 & 4.1 \\
\hline Eboh, Obaroefe, ${ }^{27}$ Southern region of Nigeria & Not specified & 100 & 83 & 5 & 6 & 6 \\
\hline Natekar et al,14 India & Not specified & 300 & 85.33 & 8 & 51.4 & 10.6 \\
\hline Oguz et al, ${ }^{26}$ Turkey & Not specified & 52 & 88 & 10 & 2 & 0 \\
\hline \multirow[t]{2}{*}{ Ruiz et al, ${ }^{31}$ Southeastern region of Brazil } & Male & 70 & 92.86 & 4.28 & 1.43 & 1.43 \\
\hline & Female & 40 & 85 & 5 & 7.5 & 2.5 \\
\hline Satpute, Wahane, ${ }^{15}$ Vidarbha, India & Not specified & 170 & 82.94 & 2.94 & 7.04 & 5.29 \\
\hline Seema, ${ }^{16}$ Northern India & Not specified & 100 & 89 & 7 & 12 & 4 \\
\hline Ukoha et $a l,{ }^{8}$ Southeastern region of Nigeria & Not specified & 112 & 75.5 & 19.6 & 3.6 & 1.8 \\
\hline Walulkar et al,17 Vidarbha region of Maharashtra, India & Not specified & 700 & 82.2 & 9 & 5 & 3.7 \\
\hline Agarwal et $a l_{1}^{18}$ Northern India & Not specified & 900 & 71.7 & 3.33 & 23.3 & 1.7 \\
\hline Anjana et al,12 Dakshina Kannada district of Southern India & Not specified & 64 & 82.80 & 3.1 & 9.4 & 4.7 \\
\hline Dutt et $a l,{ }^{19}$ India & Not specified & 156 & 82.7 & 3.2 & 11.54 & 2.56 \\
\hline \multirow[t]{2}{*}{ Kalthur et $a l,{ }^{20}$ Southern India } & Male & 74 & 79.75 & 0 & 18.9 & 1.35 \\
\hline & Female & 26 & 73 & 15.4 & 11.6 & 0 \\
\hline Kumar et al, ${ }^{21}$ Uttarakhand region of India & Not specified & 80 & 86.25 & 11.25 & 0 & 2.5 \\
\hline Saxena et al, ${ }^{22}$ Nigeria & Not specified & 80 & 87.79 & 10.11 & 3.79 & 5.06 \\
\hline Saxena et al, ${ }^{22}$ India & Not specified & 144 & 95.3 & 3.46 & 11.79 & 1.38 \\
\hline Nayak et al, ${ }^{23}$ India & Not specified & 100 & 85 & 0 & 10 & 5 \\
\hline Vasudha et al, ${ }^{24}$ India & Not specified & 300 & 69.33 & 5.67 & 14 & 11 \\
\hline Wadekar et al,10 India & Not specified & 110 & 74.54 & 7.27 & 14.54 & 3.63 \\
\hline Zalawadia et al, ${ }^{25}$ Western region of India & Not specified & 82 & 91.7 & 2.4 & 4.8 & 1.2 \\
\hline \multirow[t]{2}{*}{ Apinhasmit et $a l,{ }^{30}$ Thailand } & Male & 350 & 83.4 & 0.6 & 16 & 0 \\
\hline & Female & 186 & 76.9 & 2.2 & 19.9 & 1.1 \\
\hline Present study & Not specified & 98 & 85.71 & 3.06 & 8.16 & 3.06 \\
\hline
\end{tabular}

Abbreviations: EP, epipteric; FT, frontotemporal; $n$, number; SP, sphenoparietal; ST, stellate. 
Not only the pterion types are important to medical approaches, but also the morphometric parameters related to it. The pterion is an important anatomical landmark situated $\sim 4 \mathrm{~cm}$ superior the midpoint of the zygomatic arch, and $3.0 \mathrm{~cm}$ to $3.5 \mathrm{~cm}$ posterior the frontozygomatic suture. ${ }^{16,26,34}$ These distances are important for neurosurgical planning.

Many studies have standardized some distances between the pterion and some bony points to verify the population profile in order to perform surgeries and clinical decisions, and the P-FZS is one of them. We found higher values for this morpho-metric parameter when compared with studies conducted in India, ${ }^{2}$ Nigeria $^{1}$ and Thailand ${ }^{30}$ (Table 4). Similar values of the P-FZS were found in a Turkish study ${ }^{26}$ in which no comparisons regarding gender were not made.

We also found higher values for the P-MZA when compared with studies conducted in India, ${ }^{2}$ Nigeria,${ }^{1}$
Thailand ${ }^{30}$ and Turkey, ${ }^{26}$ specially on the left side and in females (Table 4).

The P-EAM presented the same trend of higher values in the present study when compared with the study performed by $\mathrm{RaO}^{3}$ (Table 4 ) in India.

These differences between distances can be explained by genetics, nutrition, and by geographic and environmental factors, ${ }^{27}$ and they show the variations among different ethnic groups, which highlights the need for accurate data to perform surgeries in this area.

The pterional approach can also be used to reach a tumor, particularly if it is located laterally, such as meningiomas in the lesser wing of the sphenoid. ${ }^{25}$ Thus, the distance between the internal aspect of the pterion and the lateral end of the sphenoid ridge is an important measurement. ${ }^{26,35}$ We did not take this measurement, and this parameter can be analyzed in future studies.

Table 4. Gender comparison of pterion measurements in different populations

\begin{tabular}{|c|c|c|c|c|c|}
\hline \multirow{2}{*}{ Population } & \multirow{2}{*}{ Gender } & \multirow{2}{*}{ n (sides) } & \multicolumn{3}{|c|}{ Measurements (mm) } \\
\hline & & & P-FZS & P-MZA & P-EAM \\
\hline \multirow[t]{2}{*}{ Seema et al, ${ }^{2}$ Mysore, India } & Male & 54 & $\begin{array}{l}\mathrm{R}: 29.4 \pm 4.8 \\
\mathrm{~L}: 29.2 \pm 6.4\end{array}$ & $\begin{array}{l}R: 39.1 \pm 3.8 \\
L: 38.5 \pm 4.3\end{array}$ & $\begin{array}{l}\mathrm{R}:-; \\
\mathrm{L}:-\end{array}$ \\
\hline & Female & 46 & $\begin{array}{l}\mathrm{R}: 28.5 \pm 4.6 \\
\mathrm{~L}: 27.8 \pm 5.9\end{array}$ & $\begin{array}{l}R: 37.9 \pm 5.0 \\
L: 34.8 \pm 3.5\end{array}$ & $\mathrm{R}:-; \mathrm{L}:-$ \\
\hline \multirow[t]{3}{*}{$\begin{array}{l}\text { Adejuwon et al, } \text { Southwestern region of } \\
\text { Nigeria }\end{array}$} & Male & 42 & $31.87 \pm 0.642$ & $39.74 \pm 0.505$ & - \\
\hline & Female & 32 & $30.35 \pm 0.8358$ & $37.95 \pm 0.657$ & - \\
\hline & Both genders & 74 & $\begin{array}{c}\text { R: } \\
31.52 \pm 0.677 \\
\text { L: } \\
30.82 \pm 0.809\end{array}$ & $\begin{array}{c}\mathrm{R}: \\
39.1 \pm 0.583 \\
\mathrm{~L}: \\
38.77 \pm 0.631\end{array}$ & $\begin{array}{l}\mathrm{R}:-; \\
\mathrm{L}:-\end{array}$ \\
\hline Gindha et al,13 Northern India & Not specified & 130 & $\begin{array}{l}\mathrm{R}: 38.71 \pm 3.1037 \\
\mathrm{~L}: 36.29 \pm 3.7307\end{array}$ & $\begin{array}{c}\text { R: } 39.00 \pm 2.5635 \\
\text { L: } 37.00 \pm 3.3481\end{array}$ & $\mathrm{R}:-; \mathrm{L}:-$ \\
\hline Rao et al, ${ }^{3}$ Telangana, India & Not specified & 140 & $\begin{array}{c}\mathrm{R}: \\
30.48 \pm 4.06 \\
\mathrm{~L}: 30.39 \pm 4.70\end{array}$ & $\begin{array}{c}\text { R: } \\
37.74 \pm 3.66 \\
L: 37.07 \pm 4.19\end{array}$ & $\begin{array}{c}\mathrm{R}: \\
51.81 \pm 4.08 \\
\mathrm{~L}: 51.54 \pm 3.89\end{array}$ \\
\hline $\begin{array}{l}\text { Eboh, Obaroefe, }{ }^{27} \text { Southern } \\
\text { region of Nigeria }\end{array}$ & Not specified & 100 & $\begin{array}{c}\mathrm{R}: \\
32.06 \pm 2.62 \\
\mathrm{~L}: 31.08 \pm 2.24\end{array}$ & $\begin{array}{c}\mathrm{R}: \\
40.22 \pm 2.98 \\
\mathrm{~L}: 39.52 \pm 3.32\end{array}$ & $\begin{array}{l}\mathrm{R}:-; \\
\mathrm{L}:-\end{array}$ \\
\hline Oguz et al, ${ }^{26}$ Turkey & Male & 52 & $\begin{array}{c}\mathrm{R}: 33.30 \pm 4.0 \\
\mathrm{~L}: 34.4 \pm 3.9\end{array}$ & $\begin{array}{l}\mathrm{R}: 40.5 \pm 3.9 \\
\mathrm{~L}: 38.5 \pm 2.5\end{array}$ & $\begin{array}{l}\mathrm{R}:-; \\
\mathrm{L}:-\end{array}$ \\
\hline $\begin{array}{l}\text { Ukoha et al, }{ }^{8} \text { Southeastern region } \\
\text { of Nigeria }\end{array}$ & Not specified & 112 & $\begin{array}{l}\mathrm{R}: 27.4 \pm 0.7 \\
\mathrm{~L}: 27.4 \pm 0.6\end{array}$ & $\begin{array}{c}\mathrm{R}: 40.02 \pm 0.5 \\
\mathrm{~L}: 40.01 \pm 0.3\end{array}$ & $\begin{array}{l}\text { R: -; } \\
\text { L: - }\end{array}$ \\
\hline $\begin{array}{l}\text { Walulkar et al, }{ }^{17} \text { Vidarbha region } \\
\text { of Maharashtra, India }\end{array}$ & Not specified & 700 & $\begin{array}{l}\mathrm{R}: 27.2 \pm 0.6 \\
\mathrm{~L}: 27.0 \pm 0.5\end{array}$ & $\begin{array}{l}\mathrm{R}: 40.1 \pm 0.5 \\
\mathrm{~L}: 39.2 \pm 0.3\end{array}$ & $\begin{array}{l}\mathrm{R}:-; \\
\mathrm{L}:-\end{array}$ \\
\hline Dutt et al,19 India & Not specified & 156 & $\begin{array}{c}\mathrm{R}: \\
29.35 \pm 3.60 \\
\mathrm{~L}: 27.37 \pm 5.80\end{array}$ & $\mathrm{R}:-; \mathrm{L}:-$ & R: -; L: - \\
\hline
\end{tabular}


Table 4. (Continued)

\begin{tabular}{|c|c|c|c|c|c|}
\hline \multirow{2}{*}{ Population } & \multirow{2}{*}{ Gender } & \multirow{2}{*}{ n (sides) } & \multicolumn{3}{|c|}{ Measurements (mm) } \\
\hline & & & P-FZS & P-MZA & P-EAM \\
\hline Kalthur et al,20 Southern India & Not specified & 100 & $\begin{array}{l}\mathrm{R}: 33.2 \pm 5.0 \\
\mathrm{~L}: 32.3 \pm 5.3\end{array}$ & $\begin{array}{l}\mathrm{R}: 40.5 \pm 4.3 \\
\mathrm{~L}: 39.0 \pm 3.6\end{array}$ & R: -; L: - \\
\hline Nayak et $a l,{ }^{23}$ India & Not specified & 100 & $\begin{array}{l}\mathrm{R}: 34.8 \pm 2.1 \\
\mathrm{~L}: 34.1 \pm 1.6\end{array}$ & $\begin{array}{l}\mathrm{R}: 40.1 \pm 1.9 \\
\mathrm{~L}: 39.4 \pm 2.0\end{array}$ & $\begin{array}{l}\text { R: -; } \\
\text { L: - }\end{array}$ \\
\hline $\begin{array}{l}\text { Anjana et al,12 Dakshina Kannada, } \\
\text { Southern India }\end{array}$ & Not specified & 64 & $\begin{array}{l}\mathrm{R}: 30 \pm 4.0 \\
\mathrm{~L}: 29 \pm 2.0\end{array}$ & $\begin{array}{l}\mathrm{R}: 40 \pm 5.0 \\
\mathrm{~L}: 40 \pm 2.0\end{array}$ & $\begin{array}{l}\mathrm{R}:-; \\
\mathrm{L}:-\end{array}$ \\
\hline $\begin{array}{l}\text { Sucharitha and Bajpe, }{ }^{36} \\
\text { Karnataka, India }\end{array}$ & Not specified & 200 & $\begin{array}{c}\mathrm{R}: \\
30.62 \pm 4.24 \\
\mathrm{~L}: 30.38 \pm 4.22\end{array}$ & $\begin{array}{c}\text { R: } \\
37.83 \pm 3.10 \\
L: 37.99 \pm 31.6\end{array}$ & $\begin{array}{l}\text { R: -; } \\
\text { L: - }\end{array}$ \\
\hline Wadekar et al, India & Not specified & 110 & $\begin{array}{l}\mathrm{R}: 32.27 \\
\mathrm{~L}: 31.86\end{array}$ & $\begin{array}{l}\text { R: } 36.63 \\
\text { L: } 37.12\end{array}$ & $\begin{array}{l}\mathrm{R}:-; \\
\mathrm{L}:-\end{array}$ \\
\hline $\begin{array}{l}\text { Zalawadia et al, }{ }^{25} \text { Western region of } \\
\text { India }\end{array}$ & Not specified & 84 & $\begin{array}{l}\mathrm{R}: 37.3 \pm 5.1 \\
\mathrm{~L}: 35.5 \pm 4.2\end{array}$ & $\begin{array}{l}\mathrm{R}: 31.2 \pm 4.4 \\
\mathrm{~L}: 29.7 \pm 3.3\end{array}$ & R: -; L: - \\
\hline $\begin{array}{l}\text { Aksu et al, }{ }^{7} \text { West Anatolian region } \\
\text { of Turkey }\end{array}$ & Not specified & 256 & $\begin{array}{c}\mathrm{R}: \\
31.80 \pm 4.51 ; \\
\mathrm{L}: 31.44 \pm 4.73\end{array}$ & $\begin{array}{c}\text { R: } \\
40.02 \pm 4.06 \\
L: 39.88 \pm 4.01\end{array}$ & $\begin{array}{l}\text { R: -; } \\
\text { L: - }\end{array}$ \\
\hline \multirow[t]{2}{*}{ Apinhasmit et al, ${ }^{30}$ Thailand } & Male & 350 & $\begin{array}{c}\mathrm{R}: \\
31.73 \pm 4.95 \\
\mathrm{~L}: 31.67 \pm 5.13\end{array}$ & $\begin{array}{c}\mathrm{R}: \\
38.92 \pm 4.82 \\
\mathrm{~L}: 38.16 \pm 4.12 \\
\end{array}$ & $\begin{array}{l}\text { R: }-; \\
\text { L: - }\end{array}$ \\
\hline & Female & 186 & $\begin{array}{c}\mathrm{R}: \\
30.27 \pm 4.37 \\
\mathrm{~L}: 29.83 \pm 4.51 \\
\end{array}$ & $\begin{array}{c}\mathrm{R}: \\
38.87 \pm 4.15 \\
\mathrm{~L}: 37.85 \pm 4.12\end{array}$ & $\begin{array}{l}\text { R: -; } \\
\text { L: - }\end{array}$ \\
\hline \multirow[t]{2}{*}{ Present study } & Male & & $\begin{array}{l}\mathrm{R}: 35.06 \pm 6.33 \\
\mathrm{~L}: 34.89 \pm 4.63\end{array}$ & $\begin{array}{c}\mathrm{R}: \\
42.43 \pm 3.98 \\
\mathrm{~L}: 42.22 \pm 5.01\end{array}$ & $\begin{array}{c}\mathrm{R}: \\
58.09 \pm 3.17 \\
\mathrm{~L}: 58.70 \pm 3.59 \\
\end{array}$ \\
\hline & Female & & $\begin{array}{c}\mathrm{R}: \\
34.58 \pm 6.20 \\
\mathrm{~L}: 32.89 \pm 6.93\end{array}$ & $\begin{array}{c}\mathrm{R}: \\
41.42 \pm 4.69 \\
\mathrm{~L}: 41.42 \pm 5.17\end{array}$ & $\begin{array}{c}\text { R: } \\
56.06 \pm 4.17 \\
\text { L: } 57.04 \pm 3.78\end{array}$ \\
\hline
\end{tabular}

Abbreviations: L, left; $n$, number; P-EAM, distance from the pterion to the center of the external acoustic meatus; P-FZS, distance from the pterion to the frontozygomatic suture; P-MZA, distance from the pterion to the midpoint of the zygomatic arch; R, right.

\section{Conclusion}

The present study showed a similar pattern of incidence of pterion types when compared with the data in the current literature, but different values for all morphometric parameters analyzed. We hope that the present study may contribute to anthropological and pathological studies, and also help neurosurgeons use this craniometric point to access a variety of brain lesions in individuals from the Northeastern region of Brazil, decreasing the rates of iatrogenic lesion and increasing the rates of successful outcomes.

\section{References}

1. Adejuwon SA, Olopade FE, Bolaji M. Study of the location and morphology of the pterion in adult nigerian skulls. ISRN Anat 2013;2013:403937.

2. Seema D, Dakshayani KR, Sumanth MM. A Morphometric Study of Pterion in Adult Human Skulls. International Journal of Recent Trends in Science And Technology 2013;9(01):112-115.

3. Rao KEV, Rao BS, Vinila BS. Morphology and morphometric analysis of pterion with its neurosurgical implications in pterional approach. Int J Anat Res 2017;5(01):3384-3388.

4. Murphy T. The pterion in the Australian aborigine. Am J Phys Anthropol 1956;14(02):225-244.

5. Broek AJP. On pteric sutures and pteric bones in the human skull. KNAW Proceedings Series B Pshysical Sciences 1913;16(02): 634-639

6. Sindel A, Ögüt E, Aytaç G, Oguz N, Sindel M. Morphometric study of pterion. Int J Anat Res 2016;4(01):1954-1957.

7. Aksu F, Akyer SP, Kale A, Geylan S, Gayretli O. The localization and morphology of pterion in adult West Anatolian skulls. J Craniofac Surg 2014;25(04):1488-1491.

8. Ukoha U, Oranusi CK, Okafor J, Udemezue OO, Anyabolu AE, Nwamarachi TC. Anatomic study of the pterion in Nigerian dry human skulls. Niger J Clin Pract 2013;16(03):325-328.

9. Vanrell JP. Odontologia legal e antropologia forense. 1st ed. Rio de Janeiro: Guanabara Koogan; 2002:224-231.

10. Wadekar PR, Supare MS, Gat NF, Pandit SV. Study of Morphology and Location of the Pterion. Int J Sci Res (Ahmedabad) 2017;6(07): 259-261.

11. Carolineberry A, Berry RJ. Epigenetic variation in the human cranium. J Anat 1967;101(Pt 2):361-379.

12. Anjana S, Satheesa KS, Bhaskar R, Pai SR. Morphometric study of 
pterion in adult dry skulls in Dakshina Kannada district, Karna- taka state, India. Int J Anat Res 2015;3(04):1603-1606.

13. Gindha GS, Mir NS, Agarwal R. Morphometric Study of Pterion in Dry Human Skull Bone in North Indian Population. Human Biology Review 2017;6(01):1-9.

14. Natekar PE, DeSouza FM, Natekar SP. Pterion: An anatomical variation and surgical landmark. Indian Journal of Otology 2011;17(02):83-86.

15. Satpute C, Wahane A. To study the morphology of pterion in dry human skull in Vidarbha region. Inter J of Science and Research 2013;4(01):2171-2173.

16. Seema MA. Pterion formation in North Indian population: an anatomico-clinical study. Int J Morphol 2014;32(04):1444-1448.

17. Walulkar S, Dehankar R, Walulkar M, Ksheersagar DD. Pterion formation and its variations in Human Skull in Vidarbha Region. J Cont Med. Dent 2016;4(02):58-61

18. Agarwal AK, Singh PJ, Gupta SC, Gupta CD. Pterion formation and its variations in the skulls of Northern India. Anthropol Anz 1980; 38(04):265-269.

19. Dutt V, Shankar VV, Shetty S. Morphometric Study of Pterion and Asterion in Adult Human Skulls of Indian Origin. Int J Anat Res 2017:5(2.2):3837-3842.

20. Kalthur SG, Vangara SV, Kiruba L, Dsouza AS, Gupta C. Metrical and non-metrical study of the pterion in South Indian adult dry skulls with notes on its clinical importance. Marmara Medical Journal 2017;30(01):30-39.

21. Kumar S, Munjal S, Chauhan P, Chaudhary A, Jain SK. Pterion its location and clinical implications a study compared. Journal of Evolution of Medical and Dental Sciences 2013;2(25):4599-4609 22. Saxena SK, Jain SP, Chowdhary DS. A comparative study of pterion formation and its variations in the skulls of Nigerians and Indians. Anthropol Anz 1988;46(01):75-82.

23. Nayak G, Mohanty BB, Das SR. Morphometric Study of Pterion And its Clinical Significance. Asian J Pharm Clin Res 2017;10(10):142-144.

24. Vasudha TK, Divya SDS, Gowd S. Study of Morphology of Pterion and its Clinical Implications. Int J Anat Res 2017;5(4.3):4674-4678.

25. Zalawadia A, Vadgama J, Ruparelia S, Patel S, Rathod SP, Patel SV.
Morphometric study of pterion in dry skull of Gujarat region. Natl J Integr Res Med 2010;1(04):25-29.

26. Oguz O, Şanli SG, Bozkir MG, Soames RW. The pterion in Turkish male skulls. Surg Radiol Anat 2004;26(03):220-224.

27. Eboh DEO, Obaroefe M. Morphometric study of pterion in dry human skull bones of Nigerians. Int J Morphol 2014;32(01):208-213

28. Mwachaka PM, Hassanali J, Odula P. Sutural morphology of the pterion and asterion among adult Kenyans. Braz J Morphol Sci 2009;26(01):4-7.

29. Avalos RM, Alvarado MVA, Omaña REE, López SG. Estudio morfológico del pterion y asterion en cráneos adultos mexicanos. Rev Arg de AnatClín 2011;3(02):77-83.

30. Apinhasmit W, Chompoopong S, Chaisuksunt V, Thiraphatthanavong $P$, Phasukdee N. Anatomical consideration of pterion and its related references in Thai dry skulls for pterional surgical ap- proach. J Med Assoc Thai 2011;94(02):205-214.

31. Ruiz CR, Souza GC, Scherb TO, Nascimento SRR. Anatomical variations of pterion: analysis of the possible anatomical variations of pterion in human skulls. Journal of Morphological Sciences 2016;33(04):200-204.

32. Saheb SH, Haseena S, Prasanna LC. A study of sutural morphology of the pterion and asterion among human adult Indian skulls. Biomed Res 2011;22(01):73-75.

33. Patten CJ. Cranium of an adolescent Chimpanzee showing bilateral and symmetrical complete bipartite division of the parietals, with multipartite division of the upper segments, with remarks on the significance of parietal division. Z Morphol Anthropol 1912;3:527-608. 34. Ersoy M, Evliyaoglu C, Bozkurt MC, Konuskan B, Tekdemir I, Keskil IS. Epipteric bones in the pterion may be a surgical pitfall. Minim Invasive Neurosurg 2003;46(06):363-365.

35. Lama M, Mottolese C, Alvisi C, Riccio A. Middle meningeal artery aneurysm associated with meningioma. J Neurosurg Sci 2000;44 (01):39-41.

36. Sucharitha A, Bajpe R. Study of anatomic position of Pterion in dry human skulls in Karnataka. Sch J App Med Sci 2016;4(9B):3272-3276
Received: May 15, 2019

Accepted: October 18, 2019
Corresponding author

André de Sá Braga Oliveira

Email: andre.sboliveira@gmail.com 